\title{
Study of the Adaptation Process as a Local Community Strategy in Social Transformation of Samin Group of Indonesia
}

\author{
Kridawati Sadhana, Yustina Ndung, and Tommy Hariyanto \\ Faculty of Social and Political Sciences, University of Merdeka Malang, Indonesia
}

\begin{abstract}
The Samin community is an indigenous community with its unique and unique culture. The presence of modern culture in the traditional environment has implications for the emergence of a new order in the culture of the Samin group. The Samin people who initially did not like to mix with other groups except with their own group, became more open to accept new things in their community. These changes encourage researchers to study the Adaptation process as a Local Community Strategy in Social Transformation. Data collected through interviews, observation and documentation. Data analysis uses interactive design. The results of this study indicate that: First, the adaptation of the Samin people develops from an evolutionary understanding that humans always try to adapt to their surroundings, both biologically / genetically and culturally. Second, the social behavior carried out by the Samin community is an objective condition united with a collective commitment to a value influenced by the social system, cultural system, and personality system of each individual. Third, the social transformation of the Samin community is influenced by internal and external factors, which is the result of a process that very complex of various social, economic, political, and cultural sub-systems. Fourth, the social life of the Samin people is fundamentally an organic evolution, that society is ideally democratic, moral, and progressive.
\end{abstract}

Keywords: Adaptation, Social Transformation, Local wisdom, Samin Community, Culture.

\section{INTRODUCTION}

The country of Indonesia consists of thousands of islands inhabited by diverse ethnic and cultural groups. A country with thousands of islands is called an archipelago. The motto of the Unitary Republic of Indonesia (NKRI) is the Unity in Diversity based on the Pancasila and the 1945 Constitution. The Indonesian nation consists of 17,540 Islands, 1,211 Languages and 1,340 Ethnic Groups with diverse Customs, Traditions, Culture and Religion or Religion and belief in God Almighty. The religiosity of Indonesian society is based on the awareness that humans are created in the most perfect circumstances by being given the excess of creativity, taste and intention or reason, mind and work. Through human reason can work by always getting closer to the Creator and friendly with nature and all creation.

One part of the Indonesian nation that has cultural distinctiveness is the Samin community with its distinctive and unique socio-cultural characteristics. The uniqueness is seen in the ways of community life, language and behavior, as well as traditions that are maintained for generations, do not like to hang out except with their own groups. The Samin tribe at the beginning of its movement lived in groups in a different area, generally located in remote villages. The social system of the Samin community is able to withstand the penetration of global currents so that it does not eliminate its identity, but adapts to social change.

Ethnically, the Samin people are Javanese, but they differ somewhat in terms of customs and traditions from the Javanese in general. This can be seen from the attitude and behavior of the Samin community in daily life. For example, the Samin people are told to pick coconuts, so he picks all the coconuts (small) until we tell him to stop and come down. Because the concept he received was "picking coconut" meaning all coconuts (small and large). Likewise, if he was told to clean rice (weed the grass) in the paddy field, then what was revoked was rice. The grass should be pulled out so that the rice becomes 'clean' from disturbing grass. These things are considered strange by the general public and finally consider the Samin community as a 'slow or stupid' society. The Samin community wants clear and firm orders or instructions. For example in the case of picking coconuts and cleaning grass: please clean the grass that is blocking the rice plants; please pick old coconuts (how many ... mention) and when it's finished, get down right away.

The Samin community in Bojonegoro Regency is part of the East Java Province. The government recognizes it as one of the ethnic groups in East Java. However, the stigma of backwardness in the Samin community made some of the Bojonegoro people 
ashamed when he was considered a descendant of Samin. Though the teachings of Samin contain the values of simplicity, togetherness, justice, and hard work. The Samin community considers all people to be siblings, sintaw mawon kululul sedulur (whom I consider to be a brother) The honesty of his heart is summed up in thick Javanese, putéh-putéh, brother-sister (whitewhite, red-red). If true is said to be true and if false is said false (Sijayanto, 2006) [1].

The Samin community as part of the national and global community is unlikely to be able to close itself from the various influences of the life of the world community. So that his life pattern showed a change. In addition to the still strong teachings of Samin in community life, transformation has also taken place through the adaptation of members of the Samin community to the influence of outside cultures. This makes the life of the Samin community in Bojonegoro different from previous assumptions. The 'backward' stigma is slowly being eroded by new values, both from outside and within the community itself. The Samin community in this village has been reached by the influence of information and technology such as the presence of radio, television, cell phones / cell phones, and others. Other luxury items are also widely seen, such as cars, motorbikes. This fact illustrates the transformation of traditional life into modern life. The process is certainly a challenge and at the same time brings problems for the community namely: on the one hand, people are reluctant to fall behind the current development of the times, but on the other hand the demand to preserve local culture and traditions has become a necessity. Because cultural values that become local wisdom can be a solution for solving people's life problems.

At the level of change, the need for adaptation studies as a strategy of local communities in social transformation. Because the Samin community has a cultural entity that still upholds the values of Saminism with unique cultural patterns and customs rules, is in social transformation with a modern culture that brings new cultural patterns and values to the community that may differ from norms and values Saminism; So that it can cause shock culture. The social reality in the Samin community was examined in this study with the title "Adaptation as a Strategy of Local Communities in Social Transformation (Phenomenology Study of Samin in Japanese Hamlet, Margomulyo Village, Bojonegoro Regency).

\section{LITERATURE REVIEW}

\subsection{Culture Based Development}

Law Number 23 of 2014 concerning Regional Government becomes the operational basis for regions in carrying out development that can guarantee a sustainable local community. That means that development interventions must be holistically and comprehensively that takes into account aspects of the needs (needs, drives, and motives) of local communities. Humans as targets and agents of development are the focus and locus of development. Humans as a target are interpreted that the purpose of development is an increase in social welfare, while as an agent of development is a democratic-participatory activity starting from the identification of needs (need assessment), planning, implementation, and evaluation / control, so that accountability and transparency occur simultaneously.

According to Inayatullah (1967), the notion of development is a change towards patterns of society that enable better realization of human values, which allows a society to have greater control over its environment and its political objectives, and which allows its citizens to gain more control better towards themselves [2]. The ultimate goal of development is social welfare in a broad sense (physical and mental welfare). Welfare is born related to the level of life, both concerning the economic and social strata, while mental well-being is related to the belief system that exists in him, how humans understand themselves and accept themselves.

The conception of development is at least related to three things, namely: First, the development objectives, which are generally directed as a pattern of movement aimed at achieving social welfare. Second, the development goals, namely humans and their activities by basing on the natural, social and supernatural environment. Third, the substance / aspect of development, which includes the development of infrastructure and basic infrastructure, economics, and socio-cultural.

An understanding of the concept of development in general and culture-based development (local community base) in this study serves to explain the adaptation process of the Samin community in the midst of social change through development interventions in all its aspects. The analysis can also help discover the values of local wisdom of the Samin community that are still relevant to be maintained and even become a reference in development planning and implementation.

\subsection{Culture}

Culture by Koentjaraningrat (1986) is described as "the whole system of ideas, actions and results of human work in the context of community life which belongs to the human self by learning" [3]. Further explained that culture can be distinguished in three forms, namely: (1) The form of culture as a complex of ideas, ideas, values, norms and regulations, (2) The form of culture as a complex of patterned actions by humans in society, and (3) The form of culture as objects created by humans. To make it easier to describe and analyze people's life patterns, the concept of culture is further divided into 7 (seven) elements, namely: (1) 
Language, (2) Knowledge system, (3) Social organization, (4) Life equipment system and technology. (5) livelihood systems of life, (6) Religious / belief systems, and (7) Arts. Understanding this culture can help explain the view of the Samin community that can influence the process of adaptation of this community to social change.

\subsection{Local Community}

Indigenous peoples are communities that live based on ancestral origins over a customary territory, social and cultural life which is governed by customary law and traditional institutions that manage the sustainability of community life (Hendarta, 2005:21) [4]; There are also other restrictions that local communities are groups of people who historically have territorial and self-identity and identify themselves as different groups (United Nations, in Hudayana, 2005: 2) [5]. Based on this understanding, the Samin community is an indigenous community that has a unique and unique way of life, cultural values as one of the ethnic groups in Bojonegoro Regency, East Java.

In an effort to empower local communities, there are several things that must be considered (can be understood as Conditions of Opportunities and Constraints), namely: (1) the value of local wisdom that can be explored and utilized to create a harmonious community life structure; (2) local communities have the potential of natural wealth, (3) enforcement of the rule of law which continues to increase the government can build togetherness in the midst of society; (4) education built by the government can improve the quality of the Indonesian population; (5) the relatively large population of local people is the basic capital of human resources for development. While the obstacles encountered, namely: (1) the territory of Indonesia that is bounded by islands creates the limitations of communication and interaction between local communities; (2) limited local human resources so productivity is still low; (3) still using local / traditional technology; (4) local people in general have low creativity; (5) narrow and incompatible democratization with law enforcement negatively impacts the interaction of local people and migrants; (6) advances in abused technology can be a medium for demands for independence for certain ethnicities who feel oppressed or marginalized; (7) the development of primordialism and narrow paternalistic culture. (6) advances in abused technology can be a medium for demands for independence for certain ethnicities who feel oppressed or marginalized; (7) the development of primordialism and narrow paternalistic culture. (6) advances in abused technology can be a medium for demands for independence for certain ethnicities who feel oppressed or marginalized; (7) the development of primordialism and narrow paternalistic culture.

\subsection{Phenomenology Study}

This study uses phenomenology, as said by Collin (in Basrowi and Sukidin, 2002: 32) says that phenomenology seeks to understand informants' understanding of phenomena that arise in their consciousness and phenomena experienced by informants and is considered as an entity, something that exists in the world [6]. Phenomenology seeks to uncover what forms of social action, social situations and society as a product of human consciousness. Humans are creatures that communicate, interact, participate and cause a purpose. The specificity of man lies in the psychic intentionality which he is aware of, which is associated with the world of meanings and meanings. The world of human meaning can be investigated by the method of phenomenology (Orleans in Basrowi and Sukidin, 2002: 38) [6]. Phenomenology studies in this study study how phenomena are experienced in consciousness, thinking, and in the actions of the Samin community. This can be traced in view of life, actions, works and activities carried out by the Samin community.

\subsection{Adaptation Theory}

Adaptation is a dynamic process because neither organism nor the environment itself is constant / hard (Hardestry, 2000: 4546) [7]. While Roy Ellen divides the stages of adaptation into 4 types, including (1) phylogenetic stages that work through the genetic adaptation of individuals through natural selection, (2) physical modification of phenotype / physical characteristics, (3) learning process, and (4) ) cultural modification. Modification of Ellen's hagi culture is supreme or top for homo sapiens, where cultural adaptation and information transmission are said to be the dominant dominant characters. Humans are born with the capacity to learn a limited set of social and cultural rules. So then the focus of adaptation attention according to Rot Ellen should be centered on the learning process, and modify the culture. The key concepts of adaptation at the individual social level then become adaptive behavior, strategic actions and synthesis of the two so-called adaptive strategies.

\subsection{Theory of Social Change}

According to Spott (in Faisal, 1990) social change is social change [8]. When viewed in terms of causes, social change includes changes that come from outside (exogenous change) and changes from within (endogenous change). Meanwhile, according to the level of possibility it is estimated that there are episodic changes (episodic changes) and patterned changes (pattern changes). Then in terms of its nature: there are unplanned changes that are undesirable changes, usually can cause contradictions Unplanned changes are undesirable changes, usually can cause conflicts that are detrimental to people's lives. Planned changes are changes to social institutions that are based on careful planning by parties who want the change (agent of 
change). These planned changes can be determined changes originating from the top (top-down) and from the bottom (bottomtop).

\subsection{Social Interaction Theory}

This theory states that social interaction is essentially symbolic interaction. Humans interact with others by conveying symbols, others give meaning to these symbols. The core view of this approach is the individual. The experts behind this perspective say that the individual is the most important thing in the concept of sociology. They see that individuals are objects that can be directly explored and analyzed through their interactions with other individuals. In this perspective it is known by the name of sociologist George Herbert Mead (1863-1931), Charles Horton Cooley (1846-1929), who focused his attention on the interaction between individuals and groups. They find these individuals using symbols, which provide signs, and words.

The study of the adaptation process of local communities in the midst of social change examines the interactions of the Samin community as individuals and as members of the local community. As individuals, attitudes and life views of the Samin community are shown in interactions with fellow citizens, religious leaders, traditional leaders and the government. And as members of the Samin community, the values of Samin's local wisdom are shown in interactions with the environment / organization, in ceremonies and patterns of cooperation between fellow citizens, and so on. The interaction is based on the awareness that every human being acts on the meanings obtained from interactions with others. Then the meaning develops and is perfected when the interaction takes place, namely through the ways in which other people behave towards something (objects / people).

\subsection{Modernization Theory}

The assumption of modernization presented by Schoorl (1980) is that modernization is a process of transformation, a change of society in all its aspects. In the economic field, modernization means the growth of industrial complexes with economic growth as the main access. In connection with economic development, most of the population where they live is shifted to the urban environment. Modern society has grown to a certain dominant type of personality. Such personality types cause people to live in and maintain modern society.

Basically, modernization is based on social change in an idealistic perspective. One of the thinkers in the idealist camp is Weber. Weber has a different opinion from Marx. The development of capitalist industry cannot be understood simply by discussing causal factors which are material and technical in nature. However, Weber also did not deny the influence of these two factors. Weber's thinking which can influence the theory of social change is from the form of rationalism that is owned. In the life of western society, the model of rationalism will color all aspects of life. In this study, the theory of modernization is useful in examining the shifts in the views and attitudes of the Samin community as a result of development interventions, advances in science and technology.

\subsection{Conceptual framework}

Socio-cultural value system is the interaction between individuals in interaction with activities in a particular setting in order to meet certain needs. Socio-cultural systems appear in institutions that live in society. In this case, the role of the government is very important in protecting, fostering and preserving local wisdom in a Samin community in Bojonegoro so that the community's identity does not disappear from the nation's noble cultural wealth. 


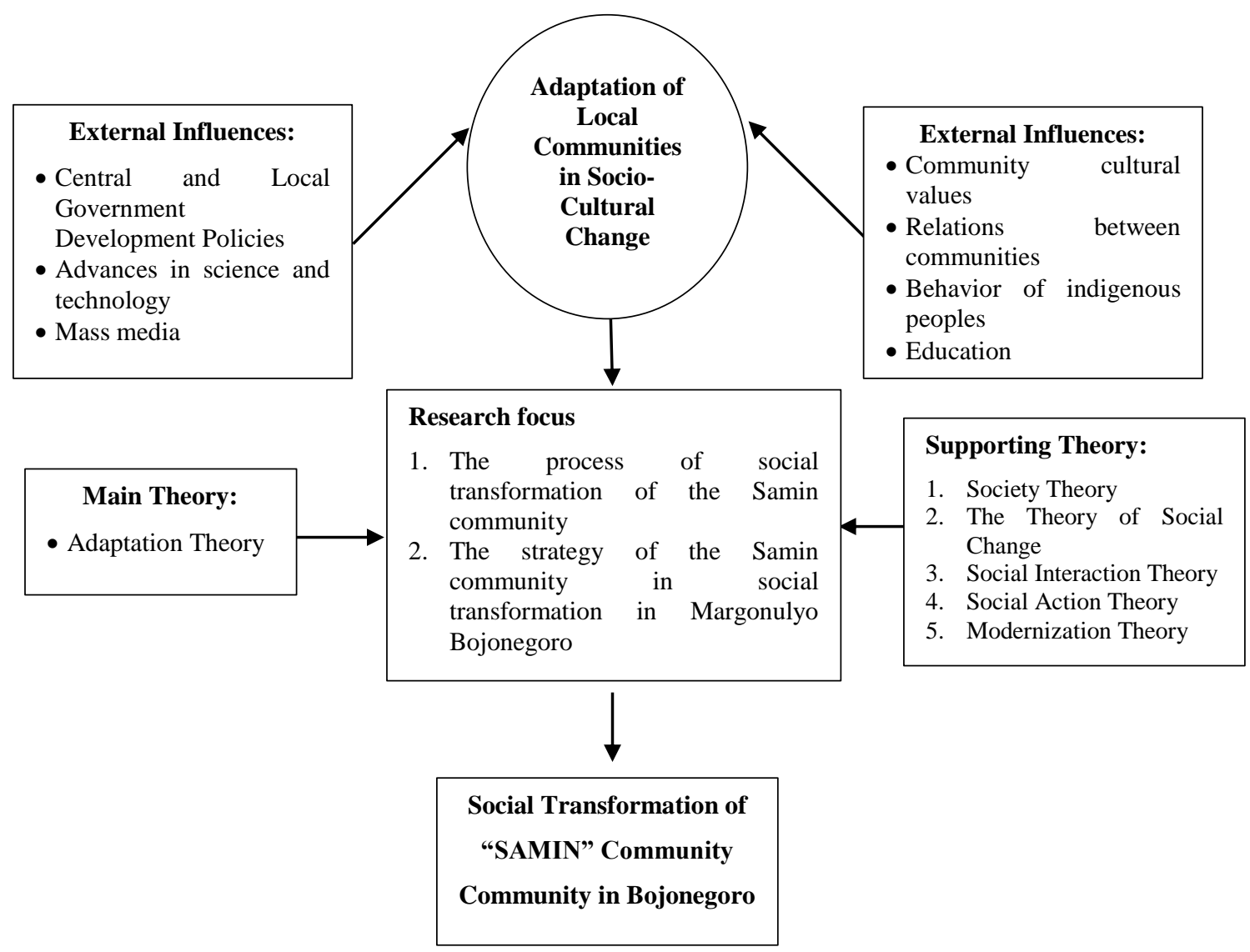

Figure 1. Conceptual Framework

\section{RESEARCH METHODS}

\subsection{Research Approach}

This research was conducted using naturalistic findings (Lincoln and Guba), an approach that looks at social reality in its natural setting, without manipulating the researcher. Different from the research conducted to test hypotheses, this research is intended to describe and reflect social reality about the adaptation of a local community group by trying to reveal the "how" and "why" the actors in each change. So the researcher wants to express the meaning of behavior according to the perspective of the actors themselves.

This approach is intended to know, understand, and reflect the meaning implicit in the reality under study, namely the meaning of socio-cultural adaptation. Socio-cultural adaptation which includes social activities, educational activities, religious activities, and other social activities.

\subsection{Research sites}

The research was carried out in the Japanese hamlet, Margomulyo village, Margomulyo District, Bojonegoro Regency, East Java Province. Determination of Japanese hamlet to be the location of research based on considerations: First, the problem under study is actual and relevant to the community. The actual and relevant research problem at this research location is because in the midst of the rapid flow of change as it is today, the Samin community still exists to maintain a very traditional socio-cultural system by simply adapting without leaving its identity and local wisdom. Second: researchers have conducted research through literature references about the Samin community which are not always true to the facts in the field.

\subsection{Collection Techniques}

Data analysis techniques in this study used interactive analysis techniques developed by Milles and Huberman in Sugiyono (2014: 244), namely data reduction, data display, and conclusion drawing / verification [9]. 


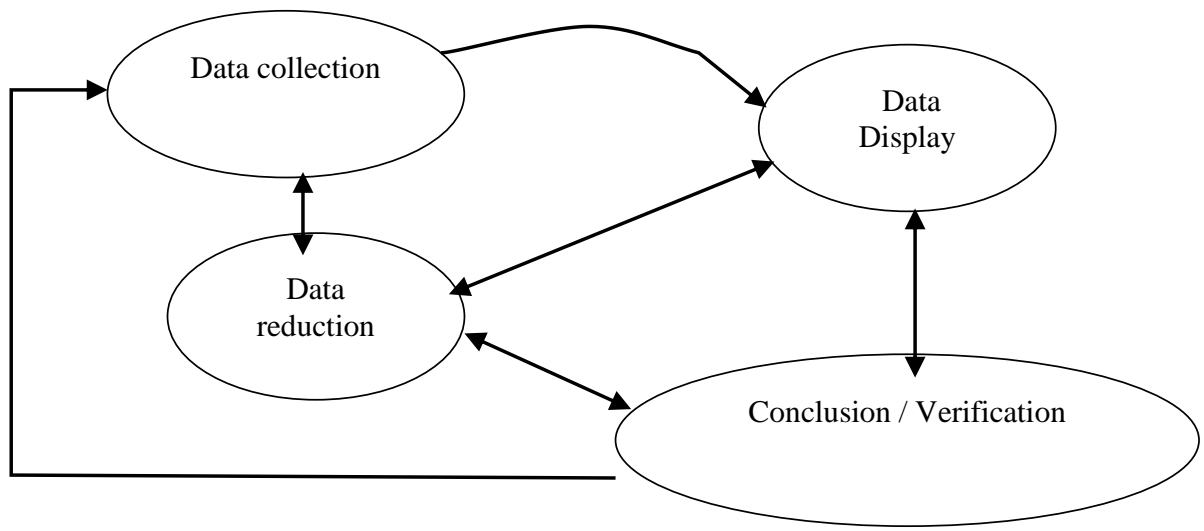

Figure 2. Miles and Huberman's Interactive Model Data Analysis

Source: Qualitative Data Analysis (Sugiyono 2014: 244) [9].

To obtain naturalistic conclusions, four types of data validity criteria can be used as introduced by Lincoln and Guba (1985: 301-308) [10], namely criteria (1) credibility (which includes sufficient time allocation in the field, conducting triangulation to strengthen references and checking research findings; (2) transferability which includes the use of samples adequately, comparing power constantly, looking for empirical events about the similarity of contexts; (3) Dependability through checking field data; (4) Confirmability through data collection, ethical-emic confirmation, discussion with research subjects, paying attention to research ethics and re-checking research results.

\section{RESULTS AND DISCUSSION}

\subsection{Overview of the Samin Community}

Japanese Hamlet is one of the eight hamlets included in the area of Margomulyo Village, Margomulyo District, Bojonegoro Regency, East Java Province. This Japanese hamlet is approximately four and a half (4.5) kilometers from the Margomulyo village office, approximately three and a half (3.5) kilometers from the Margomulyo sub-district office, approximately 70 kilometers from the capital city of Bojonegoro district, and approximately 250 kilometers from the capital city East Java Province. The Japanese hamlet covering an area of approximately 74.76 hectares is divided into two RTs, namely RT 1 and RT 2, RW 5. RT 1 is located at the top, and is limited by hamlet roads. While RT 2 is located at the bottom close to rain-fed river water flow (not permanent). In RT 2 the majority is inhabited by the Samin community.

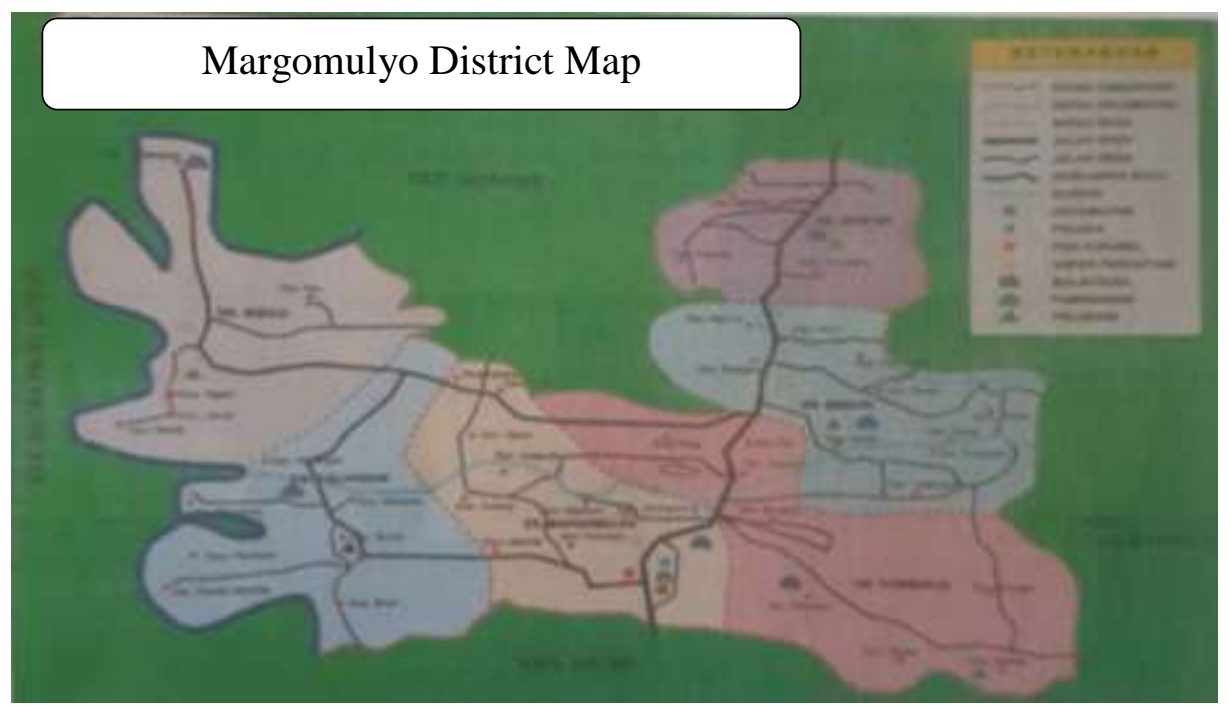

Figure 3. Margomulyo District Map

Source: Margomulyo District Profile 
The type of soil in the Japanese village is brownish-white limestone so-called rapak soil. This type of soil cannot absorb water so that when it rains it causes muddy, slippery and mud to stick like glue. While the houses where the Samin community lives are mostly semi-permanent. The roof of the house is made of tile, wooden frame, wooden walls, and the floor of the house is still in the form of a dirt floor. However, the material used for the framework and walls of the house using teak wood. Because the material is available around the environment so it is easy to use. Next to the big house, there is a side house that is used to store wood, agricultural products, a place for cooking, and a place for animal cages. Some houses have been equipped with wells and bathrooms, but everything is still in a very simple form. Because most of the members of the Samin community are farmers and ranchers, and are Muslim.

\subsection{Samin Community Social Transformation}

Analysis and reflection on the way Samin communities interact, act and regulate their social behavior, gives researchers an overview of the understanding and understanding of the Samin community for social transformation related to religious, political, technological and environmental life.

\section{a. Transformation of Samin Society in Politics}

Samin community has an assumption that the good and bad of the community depends on whether or not a leader. In the colonial era, the Samin people did not want to work together let alone submit to the invaders. They want the development to be carried out by natives. After independence, the Samin Community firmly conveyed the attitude of the teachings to their politics, namely love and loyalty to the mandate of ancestors, old wisdom, and love and respect for the government who were considered as parents and spiritual elders. The Samin people obey the traditional leaders, and accept the presence of formal leaders. The strong role models of adat leaders and the Samin community's trust in traditional leaders made them sometimes follow what was chosen by the traditional leaders. So that the political choices of the Samin people for formal leaders elected through elections tend to follow the choices of adat leaders. Then it was shifted that they remained obedient to adat leaders, but chose leaders in the elections according to their conscience (political freedom).

\section{b. Transformation of the Samin Community towards Outside Assistance (Economy)}

The Samin community is hardworking and simple. They are very careful in utilizing the nature of both the forest and their fields so as not to be damaged due to greed or exploitative actions. Even though they live in simple conditions with less fertile soil, they are not willing to accept outside assistance (including government assistance) if the assistance creates a sense of injustice. The attitude of the Samin community towards outside assistance shows economic independence. The Samin community wants to enjoy life according to their own abilities and work. They assume that asking for or proposing assistance to outsiders is taboo. The transformation that took place was that the Samin community would then accept assistance from outsiders who were not binding, or had no political intentions.

The selective attitude of the Samin community towards outside assistance characterizes economic independence and simplicity. This reality can be explained from the perspective of Talcott Parsons' social action theory that individual and group actions are influenced by the social system, culture and personality of each individual. Talcott Parsons also clarifies the types of roles in a social system, called Pattern Variables, which contain affective, self-oriented and group understanding interactions.

\section{c. Transformation of Samin Society Towards Technology Development}

The transformation of the Samin community in the field of technology can be seen in its attitude that does not reject the entry of technology products either through government assistance or brought by the community itself. They are willing to join community organizations such as the Panggih Mulyo farmer group and the Karang Bakti Youth Organization. Likewise the use of technology / mechanization in agriculture to increase agricultural production. Most of the people of Samin already have TV, cellphone, even many who can use computers and the internet. This proves that the Samin community continues to develop following the changing times. They did not reject the entry of technology amidst the strong teachings of Samin which colored the lives of its citizens.

This reality shows that the Samin community continues to develop following the changing times which are characterized by a non-averse attitude towards access to technology that is supported by increasingly widespread knowledge about the benefits and skills of using technology products. The attitude of the Samin community towards technological development shows an adaptive attitude but still avoids the negative impacts by trying to maintain local culture such as togetherness, mutual cooperation, harmony, and mutual assistance.

The openness of the Samin community to technological developments shows a process of adaptation. Adaptation is a dynamic process because neither organism nor the environment itself is constant / hard (Hardestry, 2000: 45-46) [7]. While Roy Ellen divides the stages of adaptation into four (4) types, including (1) phylogenetic stages that work through individual genetic adaptation through natural selection, (2) physical modification of phenotypes / physical characteristics, (3) learning processes, and 
(4) cultural modification. Cultural modification for Ellen to be supreme or top for homo sapiens, where the cultural adaptation and transmission of information which he said was the dominant dominant character. Humans are born with the capacity to learn an unlimited set of social and cultural rules.

\section{d. Transformation of Samin Society on the Environment}

One of the five points of the teachings of Samin Surontiko, founder of Saminism, is that it is not permissible to disturb people, fight, not be jealous, and not to take property of others. The strong principle of not doing bad to others produces Samin people who respect, love to help, sacrifice for others without strings attached. In social life, this attitude is manifested in the form of harmony, mutual assistance, and mutual assistance. According to Max Weber in Social Action theory, that individuals take an action based on experience, perception, understanding, and interpretation of a particular stimulus object or situation. This is evident among others at work during the planting and harvest. The Samin community, do not know the terms employer and laborer because they do not pay one another but splice is to help each other between farm households in turn. Social transformation in terms of the work ethic of Sedulur Sikep received a new meaning that with the inclusion of Islamic teachings, work is part of worship. So the social attitude of the Samin community is dealing with the social and natural environment based on the teachings of Saminism and Islamic teachings.

\section{e. Transformation of Samin Community Ideology / Belief}

The community has noble values contained in the philosophy of life of the community. Likewise, the Samin community in the Japanese Village of Margomulyo Bojonegoro Village. They recognize "Sang Hyang Wenang, God." The Samin community recognizes that there is a power that governs human life and the universe, so that they realize that all people are brothers, respect each other, live in harmony and help one another.

The ideology of Saminism was initially related to the teachings of the Shiva-Buddhist religion as syncretism between Hinduism and Buddhism, but was later influenced by Islam so that the majority of the Samin community now embraces Islam. Although most of the Samin community is religious, traditional rituals and traditions are still carried out, such as pregnancy, birth, circumcision, and marriage ceremonies. Social transformation is related to the belief in the acceptance of religious teachings in the Samin community until finally they agree to be Muslim. However, the special characteristics of Samin who are harmonious, tolerant, mutual cooperation and mutual respect are maintained. Thus, the attitude of the Samin community that is tolerant of the followers of religion is based on the teachings of Samin and Islam.

\subsection{Adaptation as a Community Strategy in Social Transformation}

Humans with their socio-cultural environment are a dynamic population, which gives space for individuals to work actively modifying their behavior while maintaining cultural values, overcoming certain risks to a new condition, or improvising existing conditions. In this case, adapting as an active human strategy in changing social dynamics. Thus, adaptation as a cultural response or process that is open to the process of selective modification to cope with the effects of social change. Adaptation can be called a selective reproductive strategy by adding to or expanding what the community has. Measures work based on the adaptations involved, and more importantly, on the hazards / risks to which change is adaptive (Hardestry, 243) [7].

The Samin community has special characteristics which become their identities in their daily appearance that are different from other communities around them. The symbols of the identity of the Samin community include, among others, clothes and language. They don't know the level of Javanese, so the language used is Javanese Ngoko. For them respect for others is not from the language used but the attitudes and actions shown. Samin clothing usually consists of long-sleeved clothes that do not wear collars, black. Men wear headbands. For women's clothing, the shape of a long-sleeve kebaya is limited to fabric under the kneecap or above the ankle (Mumfangati, 2004) [11]. They feel the truth and strong belief in the teachings of the heritage of Samin Surontiko as a very useful way of life. The attitude of the citizens of Samin is always followed by concrete and consistent evidence in accordance with what was received.

The main teachings of Samin Surontiko are:

1) Religion is a weapon or handle of life. Saminism does not discriminate between religions, therefore the Samin people never deny or hate religion. What's important is character in my life.

2) Don't bother people, don't fight, don't be jealous and don't like taking people's property.

3) Be patient and don't be arrogant.

4) A living human must understand his life because life is only one spirit and is carried forever. The spirit of the deceased is not dead but only takes off his clothes.

5) When talking you should be able to guard your mouth, be honest and respect each other. Trading for the Samin was prohibited because in trade there was an element of "dishonesty", nor were they allowed to accept contributions in the form of money. 
The values of local wisdom of the Samin community that can be maintained in the process of social change are related to attitudes and behavior in social life, both regarding work ethics, social ethics, and compliance with leaders. While the attitude that must be left is the attitude and treatment of officials or people who are not yet known.

\section{CONCLUSION}

First, The basic assumption of adaptation of the Samin community develops from an evolutionary understanding that always sees humans always trying to adjust to the surrounding environment, both biologically / genetically and culturally. Although the Samin community group has a certain cultural pattern, modernization has brought a new cultural pattern for the Samin community that is somewhat different from the old norms and values. The process of adaptation involves genetic selection and cultural variants which are considered the best way to solve problems in their lives. This reinforces the opinions of Hardestry (2000) [7] and Bennet (1976) [12] in Adaptation Theory.

Second, social behavior carried out by the Samin community is an objective condition that is united with a collective commitment to a value to develop a particular form of social action, and it is influenced by the social system, cultural system and personality system of each individual (Compare opinion Parson (1995) in Social Behavior theory) [13].

Third, Samin's social transformation, which is the acceptance of new ways of meeting his needs, includes knowledge, beliefs, arts, morals, customary law and every ability and habit of humans as citizens is influenced by elements of internal and external factors which are the result of a very complex process from various social, economic, political and cultural systems. Between each subsystem / factors interplay, relate and determine one another. This conclusion strengthens the opinions and theories of social change Taylor (1990) [14], and Soemardjan (1982) [15].

Fourth, The social life of the Samin community is fundamentally an organic evolution, and that the society is ideally democratic, moral and progressive. The Samin community always behaves in a conformist manner and complies with the values and norms that have been established for communication, interaction, and participation. The interactional dimension of the Samin community in social change in social change refers to changes in social relations in society, which are related to changes in frequency, social distance, mediation (channels), rules or patterns and forms and relationships of relationships. This conclusion reinforces the opinion of Cooley (1982) [16].

\section{REFERENCES}

1. Sijayanto, G dan Mayong S. Laksono "Samin: Melawan Penjajah dengan Jawa Ngoko" dalam /www.indomedia.com/intisari/2001/Juli. tulisan di akses pada tanggal 5 Februari 2006.

2. Inayatullah. 1967. Towards a Non-Western Model of Development. Honolulu: East-West Center Press.

3. Koentjaraningrat. 1986. Seri Teori-teori Antropologi-Sosial, Sejarah Teori Antropologi. UI Press, Jakarta.

4. Hendarta, Bambang. 2005. Tantangan Pemberdayaan Masyarakat Adat di Kabupaten Landak, Proponsi Kalimantan Barat. Yogyakarta: IRE

5. Hudayana, Bambang. 2005. Pemberdayaan Masyarakat: Bunga Rampai Antropologi Terapan. Yogyakarta: Pustaka Pelajar.

6. Basrowi dan Sukidin, 2002, Metode Penelitian Kualitatif Perspektif Mikro, Insan Cendekia, Surabaya.

7. Hardesty. 2000. Ecological Anthropology. New York, Mc GrawHill.

8. Faisal, Sanapiah. 1990. Penelitian Kualitatif (dasar-dasar dan aplikasi). Malang: Ya3 Malang.

9. Sugiyono, 2014, Metode Penelitian Pendidikan Pendekatan Kuantitatif, Kualitatif, dan R\&D. Bandung: Alfabeta.

10. Lincoln, Yvonna S \& Egon G. Guba. 1985. Naturalistic Inquiry. California: Sage.

11. Mumfangati, 2004. Kearifan Lokal Di Lingukungan Masyarakat. Samin,Kabupaten Blora, Propinsi Jawa Tengah. Yogyakarta: Kementrian. Kebudayaan dan Pariwisata.

12. Bennet, J. W. 1976. The Ecological Transition : Cultural Antropology and Human. Adaptation. Great Britain : A. Wheaton and G. Exeter.

13. Parsons, Talcott. 1975. The Present Status of "Structural-Functional” Theory In Sociology." In Talcott Parsons, Social System and The Evolution of Action Theory New York: The Pass Perss.

14. Taylor. 1990. Manajemen Waktu Menurut Para Ahli. Jakarta: Gramedia.

15. Soemardjan, Selo. 1982. Perubahan Sosial di Yogyakarta. Yogyakarta: Gadja. Mada University Press.

16. Cooley, Charles, H. 1982. Sociologycal Theory And Social Resourches. New York : Henry Holt and Company. 